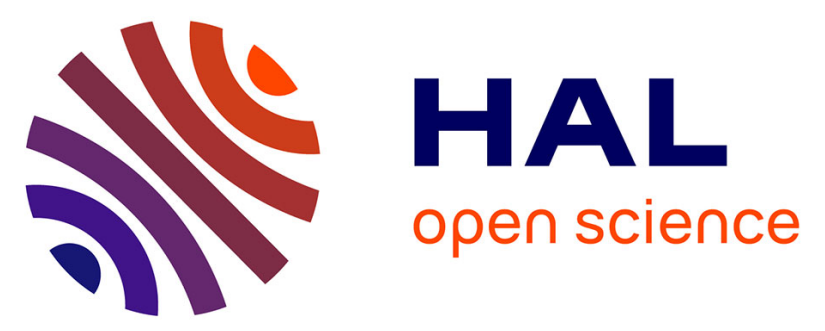

\title{
Template-Assisted Growth of Open-Ended TiO2 Nanotubes with Hexagonal Shape Using Atomic Layer Deposition
}

Thomas Cossuet, Laetitia Rapenne, Gilles Renou, Estelle Appert, Vincent Consonni

\section{To cite this version:}

Thomas Cossuet, Laetitia Rapenne, Gilles Renou, Estelle Appert, Vincent Consonni. TemplateAssisted Growth of Open-Ended TiO2 Nanotubes with Hexagonal Shape Using Atomic Layer Deposition. Crystal Growth \& Design, 2021, 21 (1), pp.125-132. 10.1021/acs.cgd.0c00952 . hal-03102060

\section{HAL Id: hal-03102060 https://hal.science/hal-03102060}

Submitted on 7 Jan 2021

HAL is a multi-disciplinary open access archive for the deposit and dissemination of scientific research documents, whether they are published or not. The documents may come from teaching and research institutions in France or abroad, or from public or private research centers.
L'archive ouverte pluridisciplinaire HAL, est destinée au dépôt et à la diffusion de documents scientifiques de niveau recherche, publiés ou non, émanant des établissements d'enseignement et de recherche français ou étrangers, des laboratoires publics ou privés. 


\title{
Template-Assisted Growth of Open-Ended $\mathrm{TiO}_{2}$ Nanotubes with Hexagonal Shape Using Atomic Layer Deposition
}

Thomas Cossuet, ${ }^{1}$ Laetitia Rapenne, ${ }^{1}$ Gilles Renou, ${ }^{2}$ Estelle Appert, ${ }^{1}$ and Vincent Consonni..${ }^{*}$ ${ }^{1}$ Univ. Grenoble Alpes, CNRS, Grenoble INP, LMGP, F-38000 Grenoble, France

${ }^{2}$ Univ. Grenoble Alpes, CNRS, Grenoble INP, SIMaP, F-38000 Saint-Martin d'Hères, France

*Corresponding author: vincent.consonni@grenoble-inp.fr

\begin{abstract}
$\mathrm{TiO}_{2}$ nanotubes have emerged as potential building blocks in nanostructured solar cells and photocatalytic devices, but the improvement of their crystalline quality and morphological control still requires further development. We report an original fabrication process to form open-ended $\mathrm{TiO}_{2}$ nanotubes in the framework of the positive template-assisted growth using $\mathrm{ZnO}$ nanowires. The process involves the combination of atomic layer deposition with post-deposition thermal treatment in air at moderate temperature to crystallize an amorphous $\mathrm{TiO}_{\mathrm{x}}$ layer into a soluble, cubic- $\mathrm{Zn}_{2} \mathrm{TiO}_{4}$ shell on the top face of $\mathrm{ZnO}$ nanowires and an insoluble, anatase- $\mathrm{TiO}_{2}$ shell with large-sized domains on their sidewalls. The differential crystallization process originates from the differential reactivity on the polar $c$ - and nonpolar $m$-plane surfaces of $\mathrm{ZnO}$ nanowires, further enhanced by the different thickness of the amorphous $\mathrm{TiO}_{x}$ layer. Following chemical etching, open-ended $\mathrm{TiO}_{2}$ nanotubes exhibit hexagonal shape and high crystalline quality with sharp, well-oriented walls. These findings open the way for integrating high quality open-ended $\mathrm{TiO}_{2}$ nanotubes with tunable length and wall thickness on a wide range of substrates. The present approach can further be developed to form other types of nanotubes and original nanowire heterostructures with highly localized, distinct phases for the shell using one simple thermal treatment.
\end{abstract}

\section{KEYWORDS}


Titanium Dioxide; Nanotubes; Template-assisted growth; Differential crystallization; Core-shell heterostructures; Transmission-electron microscopy. 


\section{INTRODUCTION}

As a long-term stable, corrosion-resistant compound semiconductor with a wide band gap energy around $3 \mathrm{eV}$ and suitable band edge positions, titanium dioxide $\left(\mathrm{TiO}_{2}\right)$ offers a large number of assets for photo-catalysis and energy conversion and storage. ${ }^{1-2}$ In most of these applications, the increase in the specific surface area by using nanostructures is of high interest for maximizing the light absorption and the efficiency of the chemical reactions with the medium. Among all the types of nanostructures, the form of nanotubes (NTs) exhibiting a high aspect ratio with a hollow inner channel has emerged as an invaluable structure in these applications..$^{3-5}$ The synthesis of $\mathrm{TiO}_{2} \mathrm{NTs}_{\text {can }}$ basically be achieved by the three following methods: ${ }^{6}$ i) electrochemical anodization of titanium foils/thin sheets, ${ }^{7-8}$ ii) hydro/solvo-thermal growth in concentrated sodium hydroxide medium, ${ }^{9-10}$ and iii) template-assisted growth using sacrificial layers. ${ }^{11-12}$ The template-assisted growth has the great advantage to readily form $\mathrm{TiO}_{2}$ NTs with a broad range of dimensions and with a high uniformity by simply tuning the morphology and size of the templates. It is further compatible with a large number of substrates including silicon and glass in contrast to the electrochemical anodization process. The most widely used positive templateassisted growth is based on the coating of $\mathrm{TiO}_{2}$ on the outer surfaces of the templates and further selective wet chemical etching to form NTs. Hoyer et al. first reported the template-assisted growth of $\mathrm{TiO}_{2} \mathrm{NTs}$ by electrochemical deposition by using an ordered alumina template with a positive polymer mold that can be dissolved by acetone. ${ }^{11}$ In addition to multi-walled carbon NTs, the use of ZnO nanowires (NWs) for the positive assisted-template growth of $\mathrm{TiO}_{2} \mathrm{NTs}$ has received an increasing interest in the last decade. The formation of $\mathrm{ZnO}$ NWs by the low-cost chemical bath deposition (CBD) technique operating at low-temperature and in aqueous solution represents an inexpensive method to fabricate highly reproducible positive templates. ${ }^{13}$

Basically, two general approaches have been established to form $\mathrm{TiO}_{2}$ NTs from the $\mathrm{ZnO} \mathrm{NW}$ templates. Lee et al. first reported the liquid phase deposition of $\mathrm{TiO}_{2} \mathrm{NTs}_{\text {s }}$ by immersing the $\mathrm{ZnO} \mathrm{NW}$ template into an aqueous solution consisting of $\left(\mathrm{NH}_{4}\right)_{2}-\mathrm{TiF}_{6}$ and boric acid. ${ }^{14}$ As such, according to a simultaneous process, the precipitation of $\mathrm{TiO}_{2}$ in the form of NTs was achieved while the dissolution of $\mathrm{ZnO}$ NWs operated. The present one-step approach has had a great success to form $\mathrm{TiO}_{2} \mathrm{NTs}$, which 
have mainly been integrated into photocatalytic devices ${ }^{15}$ and nanostructured solar cells. ${ }^{16-18}$ However, the resulting $\mathrm{TiO}_{2}$ NTs following that one-step approach are polycrystalline and easily contaminated with residual precipitates. Later, Qiu et al. reported the deposition of $\mathrm{TiO}_{2}$ shells by sol-gel process using spin/dip coating and layer-by-layer growth on $\mathrm{ZnO} \mathrm{NW}$ templates and their selective wet chemical etching in hydrochloric acid led to the formation of $\mathrm{TiO}_{2} \mathrm{NTs}^{19-21}$ The present double-step approach has had a great promise to form $\mathrm{TiO}_{2} \mathrm{NTs}$, which have also been integrated into solar cells. ${ }^{21-23}$ Nevertheless, the resulting $\mathrm{TiO}_{2}$ NTs are also polycrystalline because sol-gel processes have mostly been used. Furthermore, an additional chemical step is required to form open-ended $\mathrm{TiO}_{2} \mathrm{NTs}$, either through a final selective wet chemical etching or through an intermediate chemical capping on the top $c$-faces of $\mathrm{ZnO}$ NWs by using sodium citrate for example. ${ }^{24}$ The structural quality of $\mathrm{TiO}_{2}$ NTs using the doublestep approach has thus been limited by the use of sol-gel process to form the $\mathrm{TiO}_{2}$ shells over $\mathrm{ZnO} \mathrm{NW}$ templates.

Atomic layer deposition (ALD) is a well-known technique to form highly conformal deposits over high aspect ratio surfaces like nanoporous materials owing to the self-saturating nature of the chemisorption and surface reactions. ${ }^{25-26}$ The fabrication of porous nanostructured metal oxides like interconnected nanoparticle chains using ALD and calcination was developed on multi-walled carbon NT templates. ${ }^{27}$ On the one hand, the defective structure of multi-walled carbon NTs enhances the nucleation rate of the ALD processes, but, on the other hand, it results in the formation of defective $\mathrm{TiO}_{2}$ interconnected nanoparticle chains with a self-supporting morphology. ${ }^{28}$ In that sense, the use of ALD has a great promise, but the defective structure of multi-walled carbon NTs is not optimal. Recently, the fabrication of epitaxial $\mathrm{ZnO} / \mathrm{TiO}_{2}$ core-shell $\mathrm{NW}$ heterostructures using $\mathrm{ALD}$ and post-deposition thermal treatment for nanostructured solar cells have opened the way for developing more innovative heterostructures within such an approach. ${ }^{29}$ The double-step process is based on the initial ALD of the amorphous $\mathrm{TiO}_{\mathrm{x}}$ layer on $\mathrm{ZnO}$ NWs and its subsequent crystallization into an epitaxial anatase- $\mathrm{TiO}_{2}$ shell using post-deposition thermal treatment. That process is expected to strongly depend on the conditions used by ALD and post-deposition thermal treatment, but this has not been explored yet.

In this work, we present a double-step approach to fabricate open-ended $\mathrm{TiO}_{2} \mathrm{NTs}_{\text {in }}$ the framework of the positive template-assisted growth using $\mathrm{ZnO} \mathrm{NW}$ arrays grown by $\mathrm{CBD}$. The process involves 
the combination of ALD to form an amorphous $\mathrm{TiO}_{\mathrm{x}}$ shell over $\mathrm{ZnO} \mathrm{NW}$ arrays and a post-deposition thermal treatment in air at moderate temperature. The crystallization process of the amorphous $\mathrm{TiO}_{\mathrm{x}}$ shell on the $m$-plane sidewalls of $\mathrm{ZnO}$ NWs is found to differ from the one on their top $c$-face during the post-deposition thermal treatment. This particularity is used to form open-ended $\mathrm{TiO}_{2} \mathrm{NTs}$ with a hexagonal shape and a high crystalline quality following a selective wet chemical etching without any additional chemical step in the fabrication process.

\section{EXPERIMENTS}

2.1. Synthesis of $\mathrm{TiO}_{2}$ nanotubes. Polycrystalline $\mathrm{ZnO}$ seed layers were deposited by dip coating on silicon using a sol-gel process. Zinc acetate $\left(\mathrm{Zn}\left(\mathrm{CH}_{3} \mathrm{COO}\right)_{2} \cdot 2 \mathrm{H}_{2} \mathrm{O}\right.$, Sigma-Aldrich) and monoethanolamine (MEA, Sigma-Aldrich) were dissolved in pure ethanol to prepare the $375 \mathrm{mM}$ equimolar solution of chemical precursors. The samples were slowly dipped into the equimolar solution and gently pulled out under controlled atmosphere at a withdrawal speed of $3.3 \mathrm{~mm} / \mathrm{s}$. They were subsequently annealed successively on two hot plates kept at $300{ }^{\circ} \mathrm{C}$ for $10 \mathrm{~min}$ and at $500{ }^{\circ} \mathrm{C}$ for 1 hour, respectively. ZnO NW arrays were grown on the polycrystalline $\mathrm{ZnO}$ seed layers by CBD. Zinc nitrate $\left(\mathrm{Zn}\left(\mathrm{NO}_{3}\right)_{2} \cdot 6 \mathrm{H}_{2} \mathrm{O}\right.$, Sigma-Aldrich) and hexamethylenetetramine (HMTA, Sigma-Aldrich) were dissolved in deionized water to prepare the $30 \mathrm{mM}$ equimolar solution of chemical precursors. The samples were placed face down in a sealed reactor located in a regular oven kept at $90{ }^{\circ} \mathrm{C}$ for 3 hours. The $\mathrm{ZnO}$ NW templates were then covered with an amorphous $\mathrm{TiO}_{\mathrm{x}}$ layer by ALD using a Cambridge Nanotech F200 Fiji reactor maintained at $200{ }^{\circ} \mathrm{C}$ and at $11 \mathrm{mTorr}$. Tetrakis dimethylamino titanium beforehand heated at $75{ }^{\circ} \mathrm{C}$ and $\mathrm{H}_{2} \mathrm{O}$ were sequentially injected for $0.1 \mathrm{~s}$ in the chamber to alternately introduce the titanium and oxygen chemical precursors, respectively. A purge of $10 \mathrm{~s}$ was used after each pulse. The samples were eventually annealed in air in an oven kept at $350{ }^{\circ} \mathrm{C}$ for 3 hours for the crystallization of the amorphous $\mathrm{TiO}_{\mathrm{x}}$ layer. The selective wet chemical etching process was achieved by dipping the samples for $30 \mathrm{~s}$ into a beaker containing an aqueous solution kept at room temperature and at a low pH of 1.7 using hydrochloric acid. The samples were eventually rinsed with deionized water and dried under a nitrogen flow. 
2.2. Characterization Techniques. Field-emission gun scanning electron microscopy (FESEM) imaging was performed with a ZEISS Ultra 55 FESEM instrument. The surface of ZnO core-shell NW heterostructures was scratched with a diamond tip and the residues were put on a carbon film placed over a copper grid to prepare the specimens for transmission electron microscopy (TEM). TEM and high-resolution TEM (HRTEM) imaging was achieved with a JEOL $2010 \mathrm{LaB}_{6}$ microscope operating at $200 \mathrm{kV}$ with a $0.19 \mathrm{~nm}$ point-to-point resolution. Energy-dispersive $\mathrm{x}$-ray spectroscopy (EDS) measurements were collected by TEM with the present microscope. Automated crystal phase and orientation mapping was performed in a JEOL 2100F FEG microscope equipped with a precession module through the automated indexing of electron diffraction patterns for which a precession angle of $1.16^{\circ}$ was used. The electron diffraction patterns were recorded by using a rate of 100 frames per second with a step size of $1 \mathrm{~nm}$, resulting in a total acquisition time of 25 min per map.

\section{RESULTS AND DISCUSSION}

A schematic of the fabrication process of open-ended $\mathrm{TiO}_{2}$ NTs involving five successive steps is presented in Figure 1.
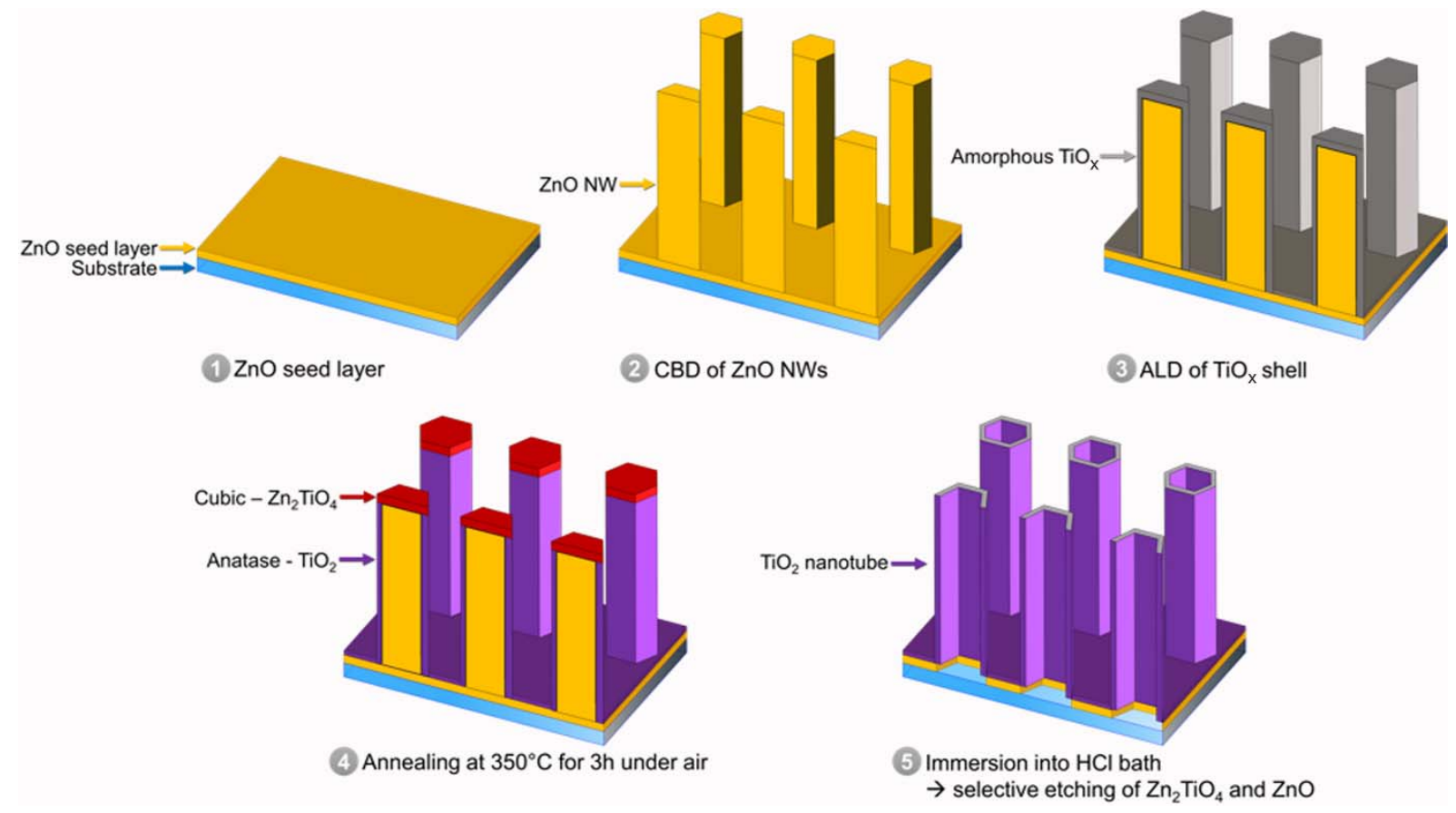

Figure 1. Schematic diagram representing the five steps required for the fabrication process of openended $\mathrm{TiO}_{2}$ NTs from a positive template made of ordered $\mathrm{ZnO}$ NW arrays. 
A $40 \mathrm{~nm}$-thick polycrystalline $\mathrm{ZnO}$ seed layer is first deposited by sol-gel process using dip coating, as seen in Figure 2a,b. ${ }^{30}$ It consists of an ensemble of compact grains with non-polar, semi-polar, and polar orientations. ${ }^{31}$ In the second step, vertically aligned $\mathrm{ZnO}$ NWs with a typical mean diameter and length of 80 and $950 \mathrm{~nm}$, respectively, are grown by CBD to create the positive template, as seen in Figure $\mathbf{2 c , d} .^{32}$ They preferentially nucleate on the grains with semi-polar and polar orientations in the textured seed layer. ${ }^{31}$ Their length can readily be tuned over a broad range of $100 \mathrm{~nm}-10 \mu \mathrm{m}$ by adjusting the concentration of chemical precursors ${ }^{32-33}$ or by using chemical additives like polyethyleneimine ${ }^{34-35}$ to reduce their radial growth. In the third step, the growth of the amorphous $\mathrm{TiO}_{\mathrm{x}}$ layer is achieved at 200 ${ }^{\circ} \mathrm{C}$ by ALD on the positive template of $\mathrm{ZnO}$ NWs. It typically results in the deposition of a conformal shell on the m-plane sidewalls of ZnO NWs from their top to their base. However, it should be noted here that the conformality by ALD is not perfect. As a result, the amorphous $\mathrm{TiO}_{\mathrm{x}}$ layer is slightly thicker (i.e. a couple of nanometers more) on the top $c$-face of $\mathrm{ZnO} N W s$ than on their $m$-plane sidewalls, which is a key parameter in the present fabrication process. The ALD processes are driven by the self-saturating nature of the chemisorption and surface reactions to ensure a perfect conformality. ${ }^{26}$ Nevertheless, given that the polar $c$-plane is much more reactive than the non-polar $m$-planes in $\mathrm{ZnO},{ }^{36}$ it is believed that the sticking probability during the ALD process of the amorphous $\mathrm{TiO}_{\mathrm{x}}$ layer is larger on the top $c$-face of $\mathrm{ZnO}$ NWs, resulting in a slightly larger thickness. In particular, the configuration of O-H groups on the surface strongly depends on the nature of the involved crystallographic plane. ${ }^{36}$ The thickness of the $\mathrm{TiO}_{\mathrm{x}}$ shell grown by ALD can be varied from a couple of nanometers to several tens of nanometers by simply adjusting the number of cycles used during the ALD process. ${ }^{37-38}$ In the fourth step, the $\mathrm{ZnO}$ core-shell NW heterostructures are annealed at $350{ }^{\circ} \mathrm{C}$ for 3 hours during a post-deposition thermal treatment in air, as seen in Figure 2e,f.

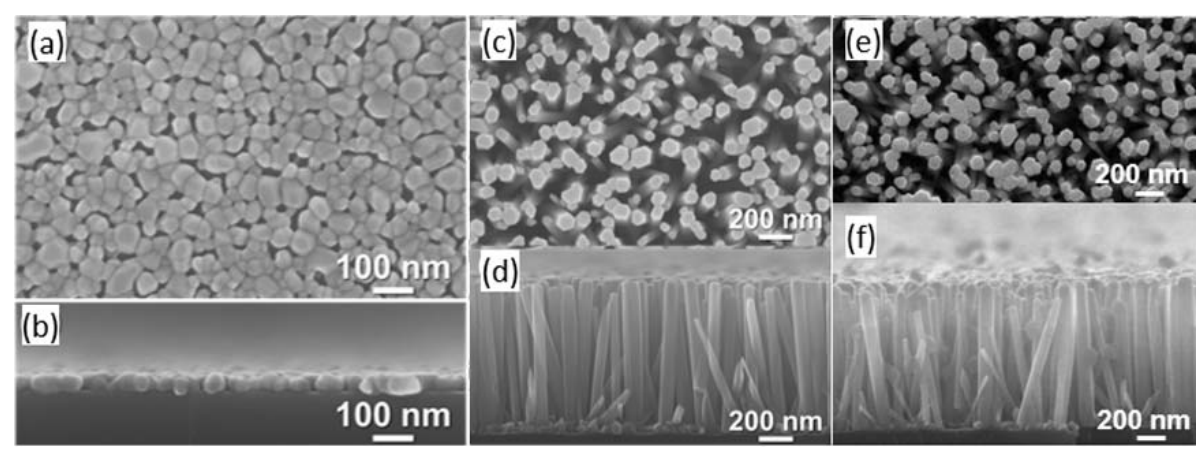


Figure 2. (a, c, e) Top-view and ( $b, d, f)$ cross-sectional view FESEM images of $(a, b)$ polycrystalline $\mathrm{ZnO}$ seed layer grown by dip coating using a sol-gel process (i.e. first step), (c, d) $\mathrm{ZnO} \mathrm{NWs} \mathrm{grown} \mathrm{by}$ CBD (i.e. second step), and (e, f) $\mathrm{ZnO}$ core-shell NW heterostructures grown by ALD (i.e. third step) and annealed at $350{ }^{\circ} \mathrm{C}$ for 3 hours in air (i.e. fourth step).

In order to investigate in detail the structural properties of $\mathrm{ZnO}$ core-shell $\mathrm{NW}$ heterostructures, TEM-based experiments were performed over a large number of nano-objects, and the overall analysis is presented in Figures 3 and $\mathbf{4}$ on a typical object. The conformality of the shell deposited by ALD on the $m$-plane sidewalls of $\mathrm{ZnO}$ NWs is very high following the post-deposition thermal treatment, as seen by the TEM image in Figure 3a. An overall thickness value of about $10 \mathrm{~nm}$ is typically measured. In contrast, the shell on the top $c$-face of $\mathrm{ZnO}$ NWs is thicker by a couple of nanometers more and reach a typical value of about $15 \mathrm{~nm}$. In that sense, the different thickness of the shell following the ALD process is kept after the post-deposition thermal treatment. Given that the TEM imaging is spatially localized on the nanometer scale, ASTAR measurements were carried out to investigate the structural properties of $\mathrm{ZnO}$ core-shell NW heterostructures on a larger scale. To decrease dynamical effects and enhance the indexing quality of electron diffraction patterns, the $2 \mathrm{~nm}$-sized incident electron beam was precessed around the optical axis. The scanning of the precessed electron beam synchronized with the recording of the experimental electron diffraction patterns at each location was achieved with a step of $1 \mathrm{~nm}$ over the area of interest. Following an automated procedure aiming at carefully comparing and matching the experimental and theoretical electron diffraction patterns as simulated for every expected crystalline phases and for a large number of orientations, ${ }^{39-40}$ the identification of both crystalline phases and orientations in the $\mathrm{ZnO}$ core-shell $\mathrm{NW}$ heterostructures was inferred with a high degree of precision. The corresponding map of the crystalline phases of $\mathrm{ZnO}$ core-shell $\mathrm{NW}$ heterostructures is presented in Figure 3b. Very interestingly, the amorphous $\mathrm{TiO}_{x}$ shell grown by ALD crystallizes into two different structures that are highly localized and spatially separated following the post-deposition thermal treatment. On the m-plane sidewalls of $\mathrm{ZnO}$ NWs, the shell exhibits a single anatase- $\mathrm{TiO}_{2}$ phase belonging to the $I 4_{1} /$ amd space group, as shown by the electron diffraction pattern in Figure 3d collected on the position $B$ in Figure 3b. Only the anatase- $\mathrm{TiO}_{2}$ phase is detected from the top to the base of $\mathrm{ZnO}$ 
NWs and its thickness is constant with a value of around $10 \mathrm{~nm}$. No sign for the presence of rutile- $\mathrm{TiO}_{2}$ phase has been revealed. Additionally, the present shell exhibits some domains with sizes that are much larger than its thickness and with a limited number of orientations, as revealed in Figure 4. Given that the ALD technique generally leads to the deposition of poorly oriented spherical grains with a size that is typically of the same order of magnitude as its thickness, the oriented large-size domains indicate local orientation relationships with the sidewalls of $\mathrm{ZnO}$ NWs through a process of local epitaxy. The presence of these large-sized domains with a high crystalline quality offers a strong asset as the coming constituting blocks in the walls of $\mathrm{TiO}_{2} \mathrm{NTs}$. The present $\mathrm{ZnO} / \mathrm{TiO}_{2}$ core-shell NW heterostructures have largely been used as electron transporting materials in nanostructured solar cells. ${ }^{37-38,}{ }^{41-42}$ In contrast, a single spinel cubic- $\mathrm{Zn}_{2} \mathrm{TiO}_{4}$ phase belonging to the $\mathrm{Fd} 3 \mathrm{~m}$ space group is specifically identified on the top $c$-face of $\mathrm{ZnO} \mathrm{NWs}$, as shown by the electron diffraction pattern in Figure 3e collected on the position $C$ in Figure 3b. The detection of that phase in the present case is technically challenging by standard characterization techniques because its overall amount is very small. The formation of that spinel phase was shown from $\mathrm{ZnO} / \mathrm{Ti}$ core-shell $\mathrm{NW}$ heterostructures ${ }^{43}$ and from $\mathrm{ZnO}$ / $\mathrm{TiO}_{2}$ core-shell NW heterostructures ${ }^{44}$ when an additional thermal treatment at a much higher temperature ranging from 800 to $900{ }^{\circ} \mathrm{C}$ activate the solid-state reaction to form multi-twinned $\mathrm{Zn}_{2} \mathrm{TiO}_{4}$ NWs. It is expected here that the annealing temperature of $350{ }^{\circ} \mathrm{C}$ is sufficient to activate the interfacial solid-solid reaction between the $\mathrm{ZnO} N W$ and $\mathrm{TiO}_{\mathrm{x}}$ amorphous shell only on their top $c$-face to form the spinel cubic- $\mathrm{Zn}_{2} \mathrm{TiO}_{4}$ phase. The present polar $c$-planes are composed of the stack of successive zinc cation and oxygen anion layers. ${ }^{36}$ They have a high surface energy ${ }^{45}$ and are known to be highly reactive, which could favour the intermixing between the different chemical elements. In contrast, the nonpolar $m$-planes are composed of the stack of successive layers with an equal number of zinc cations and oxygen anions. ${ }^{36}$ They have a much lower surface energy ${ }^{46}$ and are generally more stable. The present data further show that the nature of the crystallization process strongly depends on the thickness of the amorphous $\mathrm{TiO}_{\mathrm{x}}$ shell and on its location, either on the polar $c$ - or non-polar $m$-planes of $\mathrm{ZnO}$ to favour a differential reactivity. As the thickness is considerably decreased at nanoscale dimensions, the crystallization process further requires more and more energy and hence higher effective annealing temperatures to operate. In the present fourth step, a couple of nanometers of difference in the thickness 
of the amorphous $\mathrm{TiO}_{\mathrm{x}}$ shell grown by ALD in that range can readily switch the crystallization process from an anatase- $\mathrm{TiO}_{2}$ phase to a cubic- $\mathrm{Zn}_{2} \mathrm{TiO}_{4}$ phase on the top $c$-face of $\mathrm{ZnO}$ NWs for the same annealing temperature. The resulting $\mathrm{ZnO} \mathrm{NW}$ heterostructures with two different $\mathrm{TiO}_{2}$ and $\mathrm{Zn}_{2} \mathrm{TiO}_{4}$ shells are of high potential for photocatalytic devices ${ }^{47}$ and may enhance the degradation rate in the present double shell configuration. In contrast, when the thickness of the amorphous $\mathrm{TiO}_{\mathrm{x}}$ layer is smaller, only the anatase- $\mathrm{TiO}_{2}$ phase is formed on the top as recently reported in Ref. ${ }^{29}$. The resulting $\mathrm{ZnO} / \mathrm{TiO}_{2}$ core-shell NW heterostructures are of high interest for nanostructured solar cells for instance. ${ }^{48}$ In the present conditions of post-deposition thermal treatment for 3 hours at $350{ }^{\circ} \mathrm{C}$ in air, the thickness-dependent phase transition is abrupt and proceeds around $12-15 \mathrm{~nm}$.

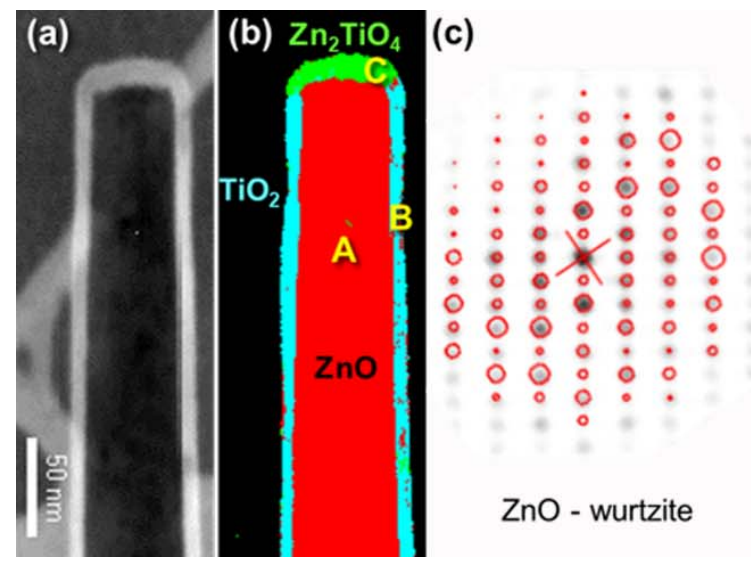

(d)

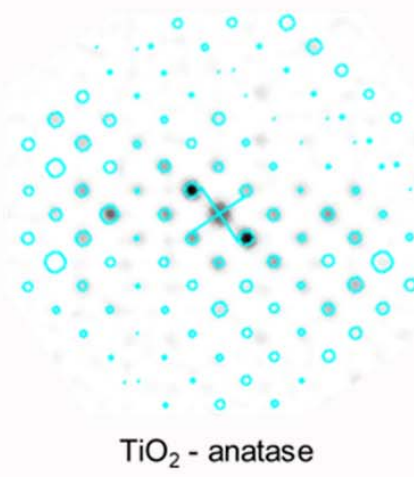

(e)

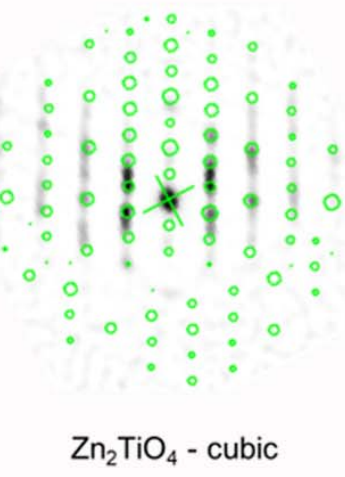

Figure 3. (a) Typical TEM image of a $\mathrm{ZnO}$ core-shell $\mathrm{NW}$ heterostructure. (b) Corresponding crystalline phase map of the $\mathrm{ZnO}$ core-shell NW heterostructure using ASTAR measurements. The wurtzite-ZnO, anatase- $\mathrm{TiO}_{2}$ and cubic- $\mathrm{Zn}_{2} \mathrm{TiO}_{4}$ phases are shown in red, blue and green, respectively. (c, d, e) Corresponding experimental electron diffraction patterns recorded at the positions $A, B$ and $C$, respectively. The red, blue and green circles indicate the theoretical electron diffraction patterns of the wurtzite- $\mathrm{ZnO}$, anatase- $\mathrm{TiO}_{2}$ and cubic- $\mathrm{Zn}_{2} \mathrm{TiO}_{4}$ phases. 


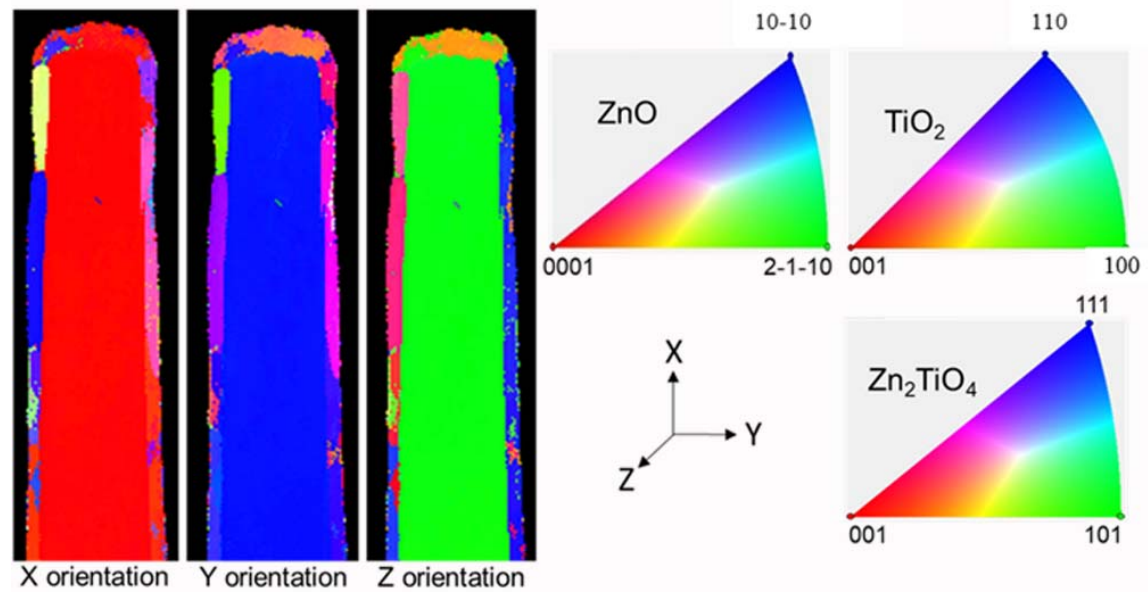

Figure 4. Crystalline orientation maps of the wurtzite $\mathrm{ZnO}$, anatase $\mathrm{TiO}_{2}$ and cubic $\mathrm{Zn}_{2} \mathrm{TiO}_{4}$ phases within the $\mathrm{ZnO}$ core-shell $\mathrm{NW}$ heterostructure along the $\mathrm{X}, \mathrm{Y}$ and $\mathrm{Z}$ axes using ASTAR measurements. The color scales for wurtzite $\mathrm{ZnO}$, anatase $\mathrm{TiO}_{2}$ and cubic $\mathrm{Zn}_{2} \mathrm{TiO}_{4}$ are presented in the insets.

Very importantly, the anatase- $\mathrm{TiO}_{2}$ and cubic- $\mathrm{Zn}_{2} \mathrm{TiO}_{4}$ phases do not exhibit the same stability in acidic medium, which is another key parameter in the present fabrication process. In the fifth step, the $\mathrm{ZnO}$ NW heterostructures with the $\mathrm{TiO}_{2}$ and $\mathrm{Zn}_{2} \mathrm{TiO}_{4}$ shells are immersed for $30 \mathrm{~s}$ into an aqueous solution kept at room temperature and at a low $\mathrm{pH}$ of 1.7 using hydrochloric acid for a selective wet chemical etching. Owing to the chemical instability of the cubic- $\mathrm{Zn}_{2} \mathrm{TiO}_{4}$ phase in acidic medium, the $\mathrm{Zn}_{2} \mathrm{TiO}_{4}$ shell on the top $c$-face of $\mathrm{ZnO} N W$ s is dissolved in hydrochloric acid along with the entire $\mathrm{ZnO}$ NW. In contrast, the anatase- $\mathrm{TiO}_{2}$ shell on the $m$-plane sidewalls of $\mathrm{ZnO}$ NWs is not affected in hydrochloric acid, forming in turn the open-ended $\mathrm{TiO}_{2} \mathrm{NTs}$ with the walls being composed of the largesized domains with a high crystalline quality. Typical TEM and FESEM images of open-ended $\mathrm{TiO}_{2}$ NTs are presented in Figures 5 and $\mathbf{6}$ along with TEM and HRTEM images of a representative nanoobject in Figure 7.

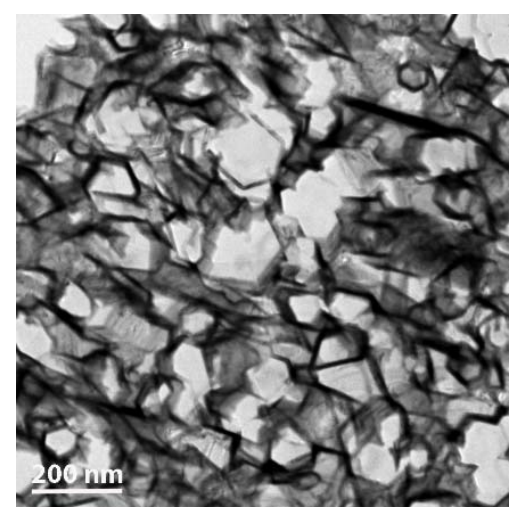


Figure. 5. Typical top-view TEM image of open-ended $\mathrm{TiO}_{2} \mathrm{NTs}$ dispersed on a carbon film on copper TEM grid.
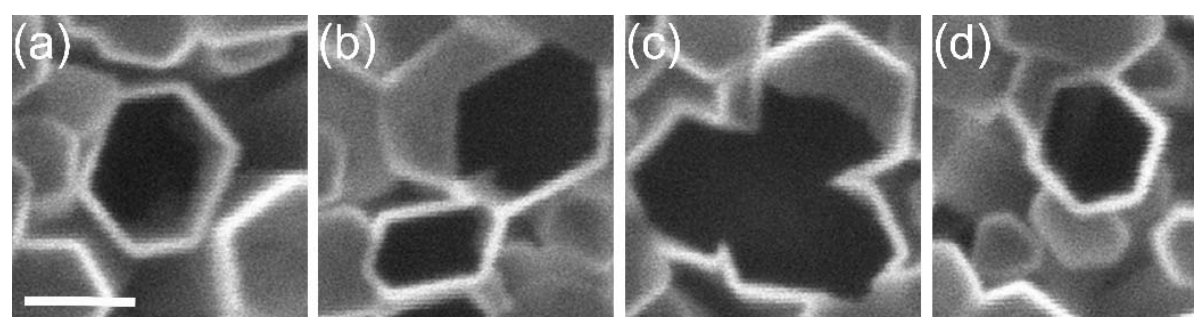

Figure 6. Typical top-view FESEM images of (a) open-ended $\mathrm{TiO}_{2} \mathrm{NT}$ with a hexagonal shape, (b) open-ended $\mathrm{TiO}_{2}$ NTs with a hexagonal and elongated shape, (c) open-ended $\mathrm{TiO}_{2} \mathrm{NT}$ with a different shape resulting from $\mathrm{ZnO} \mathrm{NW}$ initial coalescence, and (d) open-ended $\mathrm{TiO}_{2} \mathrm{NT}$ with a hexagonal shape surrounded by un-completely open $\mathrm{TiO}_{2}$ NTs. The scale bar corresponds to $100 \mathrm{~nm}$.

The open-ended $\mathrm{TiO}_{2} \mathrm{NTs}$ have an overall hexagonal shape and a high crystalline quality coming from the use of the ALD process. The TEM image of $\mathrm{TiO}_{2} \mathrm{NTs}$ dispersed on the grid shows that they are all open on their top, as seen in Figure 5. No parasitic $\mathrm{ZnO}$ phase is detected using selected area electron diffraction, indicating a complete dissolution of $\mathrm{ZnO}$ NWs owing to their high solubility at the low $\mathrm{pH}$ of 1.7. ${ }^{32}$ Instead, a $\mathrm{K}_{\alpha}$ line with a small intensity is attributed to residual $\mathrm{Zn}$ in the TEM-EDS spectra, as shown in Figure S1 of Supporting Information. Further rinsing steps can readily be used to remove the $\mathrm{Zn}$ contamination. Correlatively, the FESEM image of $\mathrm{TiO}_{2} \mathrm{NTs}$ on silicon also reveals that most of the $\mathrm{TiO}_{2}$ NTs are open on their top with the occurrence of much brighter walls, as seen in Figure 6. Some of them with a hexagonal shape have a very dark inner channel, when the $\mathrm{TiO}_{2} \mathrm{NT}$ is vertically aligned on the substrate and when the $\mathrm{ZnO}$ seed layer has been dissolved in hydrochloric acid, as seen in Figure 6a. Others present a less dark inner channel, when the $\mathrm{TiO}_{2} \mathrm{NT}$ is tilted with respect to the normal to the substrate and thus when its base on silicon is not visible. Others exhibit an elongated hexagonal shape, as seen in Figure 6b. Overall, the homogeneity of $\mathrm{TiO}_{2} \mathrm{NT}$ arrays is drastically dependent upon the distribution of $\mathrm{ZnO} \mathrm{NW}$ arrays acting as the positive template. For instance, the presence of coalesced $\mathrm{ZnO}$ NWs result in the formation of open-ended $\mathrm{TiO}_{2} \mathrm{NTs}$ with a different shape, as seen in Figure 6c. Eventually, others may not have completely been open during the selective wet chemical etching, specifically the ones with a shorter length as indicated in the proximity of the open-ended $\mathrm{TiO}_{2}$ 
NT with a hexagonal shape in Figure 6d. This inhomogeneity may come from the differential crystallization process over $\mathrm{ZnO}$ NWs with a much shorter length where the amorphous $\mathrm{TiO}_{\mathrm{x}}$ layer could be thinner. More importantly, the walls of open-ended $\mathrm{TiO}_{2} \mathrm{NTs}$ are sharp, because the anatase- $\mathrm{TiO}_{2}$ shell on the sidewalls of $\mathrm{ZnO}$ NWs is composed of domains with large sizes. They are also oriented along given directions, because the domains composing the anatase- $\mathrm{TiO}_{2}$ shell exhibit a limited number of orientation relationships with the sidewalls of $\mathrm{ZnO}$ NWs through a local epitaxy process. For instance, some walls are composed of (101) anatase- $\mathrm{TiO}_{2}$ planes, as seen in Figure 7. This is in strong contrast to the alternative processes using wet chemistry, growing a polycrystalline $\mathrm{TiO}_{2}$ shell over the $\mathrm{ZnO} N W s$ that are made of randomly oriented domains with a much smaller size. ${ }^{14,19}$ Furthermore, the wall thickness of the open-ended NTs lies in the range of $9-10 \mathrm{~nm}$ and is thus correlated directly with the thicknesses of the amorphous $\mathrm{TiO}_{\mathrm{x}}$ shell grown by ALD and of the $\mathrm{TiO}_{2}$ shell following the postdeposition thermal treatment. This offers a great opportunity as well to control the wall thickness with a high degree of precision and to reduce it as much as possible. The length of the open-ended $\mathrm{TiO}_{2} \mathrm{NTs}$ around $950 \mathrm{~nm}$ is further correlated with the length of $\mathrm{ZnO}$ NWs grown by CBD. Eventually, it is worth noticing that the fabrication process is compatible with the formation of open-ended $\mathrm{TiO}_{2} \mathrm{NTs}$ over a large number of substrates (e.g., silicon, glass, ITO/glass, metal foils, sapphire) and does not use any chemical additives that may introduce chemical pollutants or alter the surface quality. The present process has further been illustrated in the case of the spontaneous growth approach to form $\mathrm{ZnO} \mathrm{NW}$ arrays, ${ }^{32}$ but the selective area growth approach may also be employed to form ordered $\mathrm{ZnO} \mathrm{NW}$ arrays and hence to gain a larger uniformity. ${ }^{49-50}$ The possibility to form open-ended $\mathrm{TiO}_{2} \mathrm{NTs}$ with an overall hexagonal shape, a higher crystalline quality, and well-oriented walls with a tunable small thickness is of high interest in photovoltaics and photocatalysis. Furthermore, the critical fourth step in the present process devoted to one simple thermal treatment is shown to result in the fabrication of NW heterostructures with highly localized, distinct phases for the shell, opening some perspectives in the field to design original NW heterostructures. 


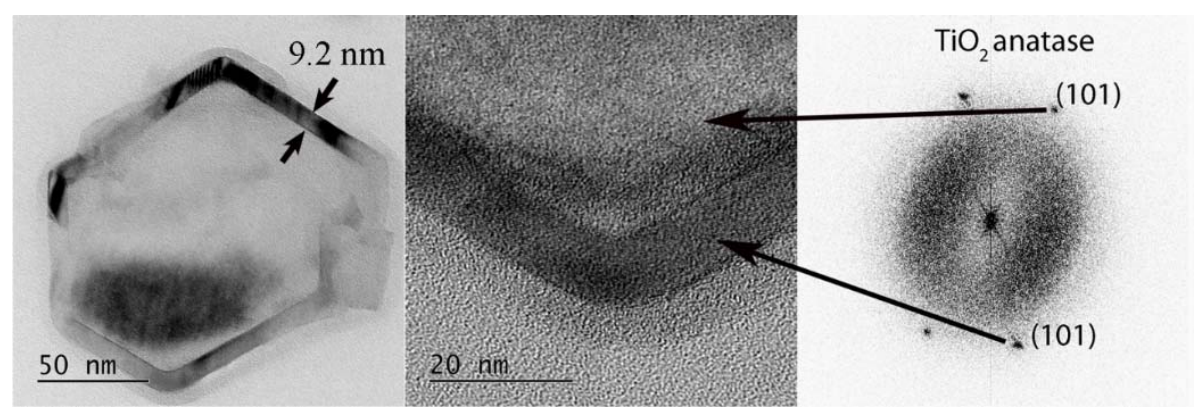

Figure 7 Top-view TEM image of an open-ended $\mathrm{TiO}_{2}$ NT (left). Corresponding HRTEM image (center) with a Fourier-filtered enhancement (right) showing that the wall is composed of (101) anatase$\mathrm{TiO}_{2}$ planes.

\section{CONCLUSIONS}

In summary, we have developed an original fabrication process to form open-ended $\mathrm{TiO}_{2} \mathrm{NTs}_{\text {in }}$ ine framework of the positive template-assisted growth using $\mathrm{ZnO}$ NWs. The fabrication process benefits from the use of ALD coupled with a post-deposition thermal treatment in air at moderate temperature. It results in the formation of a soluble, spinel cubic- $\mathrm{Zn}_{2} \mathrm{TiO}_{4}$ shell located on the top $c$-face of $\mathrm{ZnO}$ NWs and an insoluble, conformal anatase- $\mathrm{TiO}_{2}$ shell composed of domains with a large size that are highly oriented on the $m$-plane sidewalls of ZnO NWs. The differential crystallization process of the amorphous $\mathrm{TiO}_{\mathrm{x}}$ shell originates from the differential reactivity on the polar $c$ - and nonpolar $m$-plane surfaces of $\mathrm{ZnO}$ NWs that is further enhanced by its different thickness. Following an immersion into hydrochloric acid, the resulting open-ended $\mathrm{TiO}_{2} \mathrm{NTs}_{\text {s }}$ exhibit hexagonal shape and high crystalline quality with sharp and well-oriented walls without any additional chemical step in the fabrication process. These findings open the way for integrating high quality open-ended $\mathrm{TiO}_{2} \mathrm{NTs}$ with tunable length and wall thickness into nanostructured solar cells and photocatalytic devices with improved performances. The present approach is compatible with a wide range of substrates and can be extended to other types of NTs. It further highlights the possibility to design original NW heterostructures with highly localized, distinct phases for the shell using one simple thermal treatment.

\section{ACKNOWLEDGEMENTS}


This work was partly supported by the French Research National Agency through the project DOSETTE (ANR-17-CE24-0004) and by the Cross-Disciplinary Program of IDEX Université Grenoble Alpes (ANR-15-IDEX-02) through the project ECO-SESA. It has further benefited from the facilities, and the scientific and technical assistance of the CMTC characterization platform of Grenoble INP supported by the Centre of Excellence of Multifunctional Architectured Materials (LabEx CEMAM) under the contract ANR-10-LABX-44-01 funded by the "Investments for the Future" Program.

\section{ASSOCIATED CONTENT}

Typical TEM-EDS spectrum recorded on open-ended $\mathrm{TiO}_{2} \mathrm{NTs}$ following the fifth step corresponding to the selective wet chemical etching (Figure S1).

\section{REFERENCES}

1. Fujishima, A.; Zhang, X. T.; Tryk, D. A. $\mathrm{TiO}_{2}$ Photocatalysis and Related Surface Phenomena. Surf. Sci. Rep. 2008, 63, 515-582.

2. Zhang, Q. F.; Uchaker, E.; Candelaria, S. L.; Cao, G. Z. Nanomaterials for Energy Conversion and Storage. Chem. Soc. Rev. 2013, 42, 3127-3171.

3. Pang, Y. L.; Lim, S.; Ong, H. C.; Chong, W. T. A Critical Review on the Recent Progress of Synthesizing Techniques and Fabrication of $\mathrm{TiO}_{2}$-Based Nanotubes Photocatalysts. Appl. Catal. A-Gen. 2014, 481, 127-142.

4. Nasr, M.; Eid, C.; Habchi, R.; Miele, P.; Bechelany, M. Recent Progress on Titanium Dioxide Nanomaterials for Photocatalytic Applications. ChemSusChem 2018, 11, 3023-3047.

5. Mor, G. K.; Varghese, O. K.; Paulose, M.; Shankar, K.; Grimes, C. A. A Review on Highly Ordered, Vertically Oriented $\mathrm{TiO}_{2}$ Nanotube Arrays: Fabrication, Material Properties, and Solar Energy Applications. Sol. Energy Mater. Sol. Cells 2006, 90, 2011-2075.

6. Roy, P.; Berger, S.; Schmuki, P. TiO 2 Nanotubes: Synthesis and Applications. Angew. Chem.-Int. Edit. 2011, 50, 2904-2939.

7. Zwilling, V.; Darque-Ceretti, E.; Boutry-Forveille, A.; David, D.; Perrin, M. Y.; Aucouturier, M. Structure and Physicochemistry of Anodic Oxide Films on Titanium and Ta6v Alloy. Surf. Interface Anal. 1999, 27, 629-637.

8. Zwilling, V.; Aucouturier, M.; Darque-Ceretti, E. Anodic Oxidation of Titanium and Ta6v Alloy in Chromic Media. An Electrochemical Approach. Electrochim. Acta 1999, 45, 921-929.

9. Kasuga, T.; Hiramatsu, M.; Hoson, A.; Sekino, T.; Niihara, K. Formation of Titanium Oxide Nanotube. Langmuir 1998, 14, 3160-3163.

10. Kasuga, T.; Hiramatsu, M.; Hoson, A.; Sekino, T.; Niihara, K. Titania Nanotubes Prepared by Chemical Processing. Adv. Mater. 1999, 11, 1307-1311.

11. Hoyer, P. Formation of a Titanium Dioxide Nanotube Array. Langmuir 1996, 12, 1411-1413.

12. Sander, M. S.; Cote, M. J.; Gu, W.; Kile, B. M.; Tripp, C. P. Template-Assisted Fabrication of Dense, Aligned Arrays of Titania Nanotubes with Well-Controlled Dimensions on Substrates. Adv. Mater. 2004, 16, 2052-2057.

13. Vayssieres, L. Growth of Arrayed Nanorods and Nanowires of $\mathrm{ZnO}$ from Aqueous Solutions. Adv. Mater. 2003, 15, 464-466. 
14. Lee, J. H.; Leu, I. C.; Hsu, M. C.; Chung, Y. W.; Hon, M. H. Fabrication of Aligned $\mathrm{TiO}_{2}$ Nanostructured Arrays Using a One-Step Templating Solution Approach. J. Phys. Chem. B 2005, 109, 13056-13059.

15. Yuan, J. J.; Li, H. D.; Gao, S. Y.; Lin, Y. H.; Li, H. Y. A Facile Route to N-Type TiO2-Nanotube/PType Boron-Doped-Diamond Heterojunction for Highly Efficient Photocatalysts. Chem. Commun. 2010, 46, 3119-3121.

16. Charoensirithavorn, P.; Ogomi, Y.; Sagawa, T.; Hayase, S.; Yoshikawa, S. A. Facile Route to $\mathrm{TiO}_{2}$ Nanotube Arrays for Dye-Sensitized Solar Cells. J. Cryst. Growth 2009, 311, 757-759.

17. Xu, C. K.; Shin, P. H.; Cao, L. L.; Wu, J. M.; Gao, D. Ordered $\mathrm{TiO}_{2}$ Nanotube Arrays on Transparent Conductive Oxide for Dye-Sensitized Solar Cells. Chem. Mater. 2010, 22, 143-148.

18. Zhang, J.; Pauporte, T. One-Dimensional Self-Standing $\mathrm{TiO}_{2}$ Nanotube Array Layers Designed for Perovskite Solar Cell Applications. ChemPhysChem 2015, 16, 2836-2841.

19. Qiu, J. J.; Yu, W. D.; Gao, X. D.; Li, X. M. Sol-Gel Assisted ZnO Nanorod Array Template to Synthesize $\mathrm{TiO}_{2}$ Nanotube Arrays. Nanotechnology 2006, 17, 4695-4698.

20. Qui, J. J.; Jin, Z. G.; Liu, Z. F.; Liu, X. X.; Liu, G. Q.; Wu, W. B.; Zhang, X.; Gao, X. D. Fabrication of Tio2 Nanotube Film by Well-Aligned ZnO Nanorod Array Film and Sol-Gel Process. Thin Solid Films 2007, 515, 2897-2902.

21. Qiu, J. J.; Zhuge, F. W.; Lou, K.; Li, X. M.; Gao, X. D.; Gan, X. Y.; Yu, W. D.; Kim, H. K.; Hwang, Y. H. A Facile Route to Aligned $\mathrm{TiO}_{2}$ Nanotube Arrays on Transparent Conducting Oxide Substrates for Dye-Sensitized Solar Cells. J. Mater. Chem. 2011, 21, 5062-5068.

22. Na, S. I.; Kim, S. S.; Hong, W. K.; Park, J. W.; Jo, J.; Nah, Y. C.; Lee, T.; Kim, D. Y. Fabrication of Tio2 Nanotubes by Using Electrodeposited ZnO Nanorod Template and Their Application to Hybrid Solar Cells. Electrochim. Acta 2008, 53, 2560-2566.

23. Liu, Z. F.; Liu, C. C.; Ya, J.; Lei, E. Controlled Synthesis of $\mathrm{ZnO}$ and $\mathrm{TiO}_{2}$ Nanotubes by Chemical Method and Their Application in Dye-Sensitized Solar Cells. Renew. Energy 2011, 36, 1177-1181.

24. Song, H.; Jo, K.; Jung, B. Y.; Jung, G. Y. Fabrication of Periodically Aligned Vertical SingleCrystalline Anatase $\mathrm{TiO}_{2}$ Nanotubes with Perfect Hexagonal Open-Ends Using Chemical Capping Materials. Nano Res. 2014, 7, 104-109.

25. Detavernier, C.; Dendooven, J.; Sree, S. P.; Ludwig, K. F.; Martens, J. A. Tailoring Nanoporous Materials by Atomic Layer Deposition. Chem. Soc. Rev. 2011, 40, 5242-5253.

26. Cremers, V.; Puurunen, R. L.; Dendooven, J. Conformality in Atomic Layer Deposition: Current Status Overview of Analysis and Modelling. Appl. Phys. Rev. 2019, 6, 43.

27. Deng, S. R.; Kurttepeli, M.; Cott, D. J.; Bals, S.; Detavernier, C. Porous Nanostructured Metal Oxides Synthesized through Atomic Layer Deposition on a Carbonaceous Template Followed by Calcination. J. Mater. Chem. A 2015, 3, 2642-2649.

28. Deng, S. R.; Verbruggen, S. W.; He, Z. B.; Cott, D. J.; Vereecken, P. M.; Martens, J. A.; Bals, S.; Lenaerts, S.; Detavernier, C. Atomic Layer Deposition-Based Synthesis of Photoactive $\mathrm{TiO}_{2} \mathrm{Nanoparticle}$ Chains by Using Carbon Nanotubes as Sacrificial Templates. RSC Adv. 2014, 4, 11648-11653.

29. Cossuet, T.; Appert, E.; Chaix-Pluchery, O.; Roussel, H.; Rapenne, L.; Renou, G.; Sauvage, F.; Consonni, V. Epitaxial $\mathrm{TiO}_{2}$ Shell Grown by Atomic Layer Deposition on $\mathrm{ZnO}$ Nanowires Using a DoubleStep Process and Its Beneficial Passivation Effect. J. Phys. Chem. C 2020, 124, 13447-13455.

30. Guillemin, S.; Appert, E.; Roussel, H.; Doisneau, B.; Parize, R.; Boudou, T.; Bremond, G.; Consonni, V. Controlling the Structural Properties of Single Step, Dip Coated ZnO Seed Layers for Growing Perfectly Aligned Nanowire Arrays. J. Phys. Chem. C 2015, 119, 21694-21703.

31. Cossuet, T.; Roussel, H.; Chauveau, J. M.; Chaix-Pluchery, O.; Thomassin, J. L.; Appert, E.; Consonni, V. Well-Ordered Zno Nanowires with Controllable Inclination on Semipolar ZnO Surfaces by Chemical Bath Deposition. Nanotechnology 2018, 29, 11.

32. Parize, R.; Garnier, J.; Chaix-Pluchery, O.; Verrier, C.; Appert, E.; Consonni, V. Effects of Hexamethylenetetramine on the Nucleation and Radial Growth of $\mathrm{ZnO}$ Nanowires by Chemical Bath Deposition. J. Phys. Chem. C 2016, 120, 5242-5250.

33. Sugunan, A.; Warad, H. C.; Boman, M.; Dutta, J. Zinc Oxide Nanowires in Chemical Bath on Seeded Substrates: Role of Hexamine. J. Sol-Gel Sci. Technol. 2006, 39, 49-56. 
34. Parize, R.; Garnier, J. D.; Appert, E.; Chaix-Pluchery, O.; Consonni, V. Effects of Polyethylenimine and Its Molecular Weight on the Chemical Bath Deposition of ZnO Nanowires. ACS Omega 2018, 3, 12457-12464.

35. Xu, C. K.; Shin, P.; Cao, L. L.; Gao, D. Preferential Growth of Long ZnO Nanowire Array and Its Application in Dye-Sensitized Solar Cells. J. Phys. Chem. C 2010, 114, 125-129.

36. Zuniga-Perez, J., Consonni, V.; Lymperakis, L.; Kong, X.; Trampert, A.; Fernandez-Garrido, S.; Brandt, O.; Renevier, H.; Keller, S.; Hestroffer, K. et al. Polarity in GaN and ZnO: Theory, Measurement, Growth, and Devices. Appl. Phys. Rev. 2016, 3, 041303.

37. Law, M.; Greene, L. E.; Radenovic, A.; Kuykendall, T.; Liphardt, J.; Yang, P. D. ZnO-Al $\mathrm{O}_{3}$ and ZnO-TiO 2 Core-Shell Nanowire Dye-Sensitized Solar Cells. J. Phys. Chem. B 2006, 110, 22652-22663.

38. Greene, L. E.; Law, M.; Yuhas, B. D.; Yang, P. D. ZnO-TiO 2 Core-Shell Nanorod/P3HT Solar Cells. J. Phys. Chem. C 2007, 111, 18451-18456.

39. Rauch, E. F.; Veron, M. Automated Crystal Orientation and Phase Mapping in Tem. Mater. Charact. 2014, 98, 1-9.

40. Midgley, P. A.; Eggeman, A. S., Precession Electron Diffraction - a Topical Review. IUCrJ 2015, 2, 126-136.

41. Xu, C. K.; Wu, J. M.; Desai, U. V.; Gao, D. Multilayer Assembly of Nanowire Arrays for DyeSensitized Solar Cells. J. Am. Chem. Soc. 2011, 133, 8122-8125.

42. Parize, R.; Katerski, A.; Gromyko, I.; Rapenne, L.; Roussel, H.; Karber, E.; Appert, E.; Krunks, M.; Consonni, $\mathrm{V}$. $\mathrm{ZnO} / \mathrm{TiO}_{2} / \mathrm{Sb}_{2} \mathrm{~S}_{3}$ Core-Shell Nanowire Heterostructure for Extremely Thin Absorber Solar Cells. J. Phys. Chem. C 2017, 121, 9672-9680.

43. Yang, Y.; Sun, X. W.; Tay, B. K.; Wang, J. X.; Dong, Z. L.; Fan, H. M. Twinned $\mathrm{Zn}_{2} \mathrm{TiO}_{4}$ Spinel Nanowires Using ZnO Nanowires as a Template. Adv. Mater. 2007, 19, 1839-1844.

44. Yang, Y.; Scholz, R.; Fan, H. J.; Hesse, D.; Gosele, U.; Zacharias, M. Multitwinned Spinel Nanowires by Assembly of Nanobricks Via Oriented Attachment: A Case Study of $\mathrm{Zn}_{2} \mathrm{TiO}_{4}$. ACS Nano 2009, 3, 555-562.

45. Wander, A.; Schedin, F.; Steadman, P.; Norris, A.; McGrath, R.; Turner, T. S.; Thornton, G.; Harrison, N. M. Stability of Polar Oxide Surfaces. Phys. Rev. Lett. 2001, 86, 3811-3814.

46. Wander, A.; Harrison, N. M. An Ab Initio Study of ZnO(10-10). Surf. Sci. 2000, 457, L342-L346.

47. Wan, L. Y.; Li, X. Y.; Qu, Z. P.; Shi, Y.; Li, H.; Zhao, Q. D.; Chen, G. H. Facile Synthesis of $\mathrm{ZnO} / \mathrm{Zn}_{2} \mathrm{TiO}_{4}$ Core/Shell Nanowires for Photocatalytic Oxidation of Acetone. J. Hazard. Mater. 2010, 184, 864-868.

48. Consonni, V.; Briscoe, J.; Karber, E.; Li, X.; Cossuet, T. ZnO Nanowires for Solar Cells: A Comprehensive Review. Nanotechnology 2019, 30, 362001.

49. Wei, Y. G.; Wu, W. Z.; Guo, R.; Yuan, D. J.; Das, S. M.; Wang, Z. L. Wafer-Scale High-Throughput Ordered Growth of Vertically Aligned ZnO Nanowire Arrays. Nano Lett. 2010, 10, 3414-3419.

50. Consonni, V.; Sarigiannidou, E.; Appert, E.; Bocheux, A.; Guillemin, S.; Donatini, F.; Robin, I. C.; Kioseoglou, J.; Robaut, F. Selective Area Growth of Well-Ordered ZnO Nanowire Arrays with Controllable Polarity. ACS Nano 2014, 8, 4761-4770. 
FOR TABLE OF CONTENTS USE ONLY

\section{Template-Assisted Growth of Open-Ended $\mathrm{TiO}_{2}$ Nanotubes with Hexagonal Shape Using Atomic Layer Deposition}

Thomas Cossuet, ${ }^{1}$ Laetitia Rapenne, ${ }^{1}$ Gilles Renou, ${ }^{2}$ Estelle Appert, ${ }^{1}$ and Vincent Consonni..${ }^{*}$ ${ }^{1}$ Univ. Grenoble Alpes, CNRS, Grenoble INP, LMGP, F-38000 Grenoble, France

${ }^{2}$ Univ. Grenoble Alpes, CNRS, Grenoble INP, SIMaP, F-38000 Saint-Martin d'Hères, France

*Corresponding author: vincent.consonni@grenoble-inp.fr

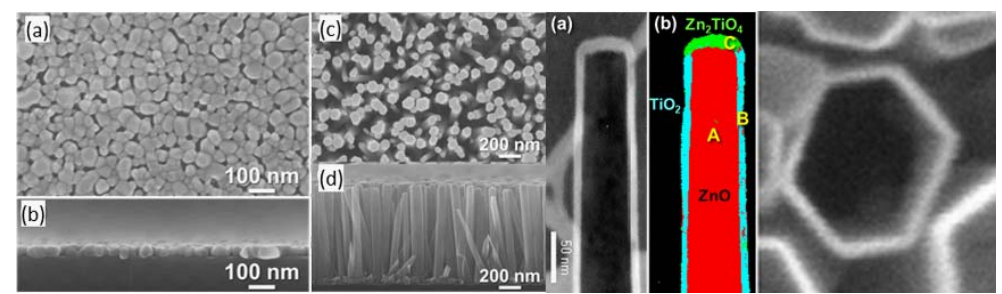

We report an original fabrication process of open-ended $\mathrm{TiO}_{2}$ nanotubes that is based on the differential crystallization of the amorphous $\mathrm{TiO}_{\mathrm{x}}$ layer grown by atomic layer deposition into a soluble $\mathrm{Zn}_{2} \mathrm{TiO}_{4}$ shell on the top face of $\mathrm{ZnO}$ nanowires and an insoluble epitaxial $\mathrm{TiO}_{2}$ shell on their sidewalls following a simple thermal treatment. 